\title{
Combined colonoscopy and laparoscopy to close a colonic perforation
}

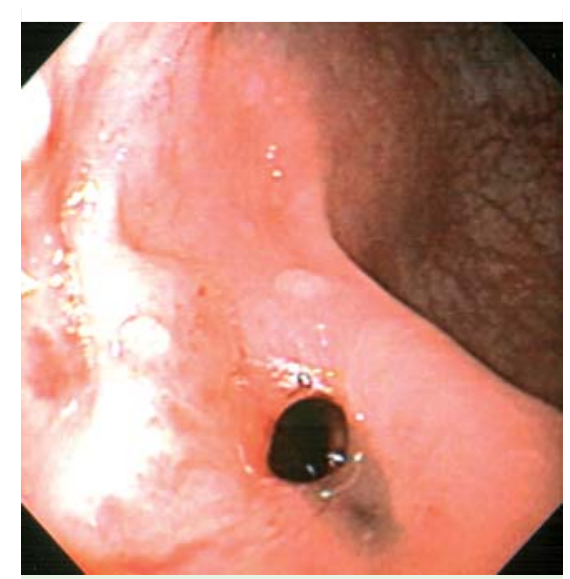

Fig. 1 Perforation visible on colonoscopy.

A 79-year-old man underwent a colonoscopy with rectal adenomatous polyp removal. As the colonoscope traversed the sigmoid colon, the operator felt a small 'pop'. An abdominal computed tomography scan revealed extraluminal air in the retroperitoneum.

Surgical consultation suggested repair of the perforation by using a combined endoscopic and laparoscopic approach. A 5-mm transmural perforation was found in the sigmoid colon ( $\bullet$ Fig. 1).

Endoclips (Resolution clips; Boston Scientific, Boston, Massachusetts, USA) were applied to the mucosal side of the perforation with a colonoscope as well as laparoscopic assistance. The laparoscope was used to manipulate the colon externally from the serosal side, bringing the perforation to face the colonoscope directly, and avoiding tangential placement of the endoclips ( $\bullet$ Fig. 2 ).

Three endoclips were deployed without complication ( $\bullet$ Fig. 3 ).

A water irrigation test was performed: the proximal bowel was clamped and then the area of repaired perforation was placed under water from the serosal side laparoscopically.

The colonoscope was then used to insufflate the bowel with air to distend it. Considerable precautions were taken to avoid air escaping from the site of the perforation. Subsequently, small numbers of air bubbles were noted. Two sutures were

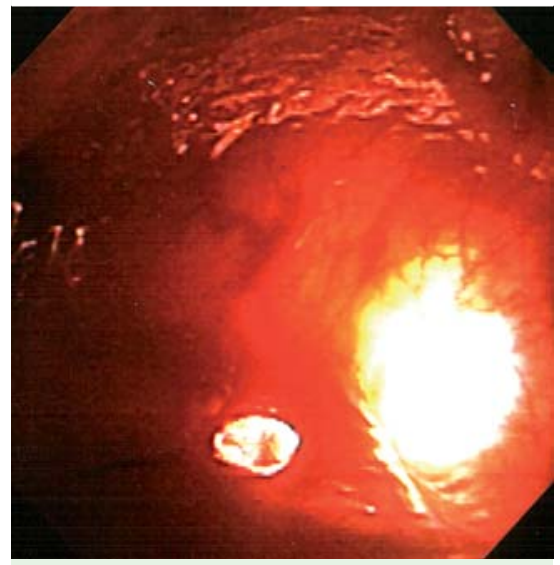

Fig. 2 Perforation site manipulated with the laparoscope.

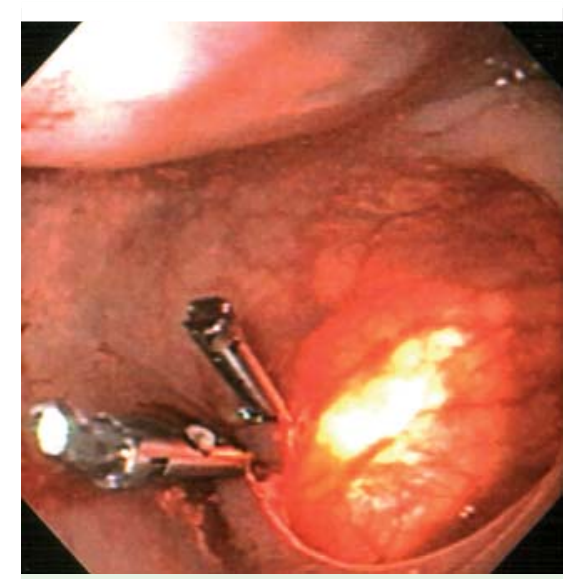

Fig. 3 Serosal transillumination of mucosal seal with endoclips.

Table 1 Salient clinical features of five cases described in the literature where endoclips were used to repair a colonic perforation.

\begin{tabular}{|c|c|c|c|c|c|}
\hline Reference & $\begin{array}{l}\text { Site of } \\
\text { perforation }\end{array}$ & $\begin{array}{l}\text { Time to } \\
\text { recognition }\end{array}$ & $\begin{array}{l}\text { Time to } \\
\text { endoscopic } \\
\text { surgery }\end{array}$ & Procedure & Discharge \\
\hline $\begin{array}{l}\text { Yoshikane } \\
\text { et al. } 1997\end{array}$ & $\begin{array}{l}\text { Descending } \\
\text { colon }\end{array}$ & Immediate & Promptly & Endoclipping & 14 days \\
\hline $\begin{array}{l}\text { Mana } \\
\text { et al. } 2001\end{array}$ & $\begin{array}{l}\text { Sigmoid } \\
\text { colon }\end{array}$ & Immediate & Promptly & Endoclipping & > 1 week \\
\hline $\begin{array}{l}\text { Dhalla } \\
2004\end{array}$ & Cecum & Immediate & Promptly & Endoclipping & $\begin{array}{l}\text { Not } \\
\text { described }\end{array}$ \\
\hline $\begin{array}{l}\text { Barbagallo } \\
\text { et al. } 2007\end{array}$ & $\begin{array}{l}\text { Right } \\
\text { flexure }\end{array}$ & Immediate & Promptly & Endoclipping & 8 days \\
\hline $\begin{array}{l}\text { Senadhi et al. } \\
\text { (December } \\
\text { 2007; current } \\
\text { report) }\end{array}$ & $\begin{array}{l}\text { Sigmoid } \\
\text { colon }\end{array}$ & Immediate & $\begin{array}{l}<12 \mathrm{~h} \text { for } \\
\text { endoscopic } \\
\text { and laparo- } \\
\text { scopic repair }\end{array}$ & $\begin{array}{l}\text { Endoclipping } \\
\text { and laparo- } \\
\text { scopic repair }\end{array}$ & 4 days \\
\hline
\end{tabular}

placed laparoscopically from the serosal side to seal the air leak. A second water irrigation test confirmed the closure of the perforation.

To our knowledge, this is the first case of colonic perforation where colonoscopy and laparoscopy were used to complete a repair effectively, without colonic resection or colostomy placement. The repair was accomplished with three steps: mucosal sealing of the perforation; an air leak test with the aid of local water irrigation (i.e. a water irrigation test); and direct observation for air bubbles during colonic air insufflation. Total serosal closure was completed with laparoscopic sutures.
Our approach with endoclips and laparoscopy provided a prompt repair of the colonic perforation and improved the outcome for the patient, who had an earlier discharge on the fourth postoperative day. - Table 1 lists four other cases [1-4] where endoclips have been used to treat colonic perforation.

Larger-scale studies are needed in order to determine whether using both laparoscopy and endoclips are superior to using endoclips alone.

\section{Competing interests: None}

Endoscopy_UCTN_Code_TTT_1AQ_2AG 


\section{Senadhi ${ }^{1}$, A. Sharma ${ }^{1}$, S. Fleischer ${ }^{2}$,}

R. Franklin², S. Dutta ${ }^{3}$

1 Johns Hopkins University/Sinai Hospital Program in Internal Medicine, Sinai Hospital, Baltimore, Maryland, USA

2 Sinai Hospital of Baltimore, Baltimore, Maryland, USA

3 Sinai Hospital of Baltimore and University of Maryland School of Medicine, Baltimore, Maryland, USA

\section{References}

1 Yoshikane H, Hidano H, Sakakibara A. Endoscopic repair by clipping of iatrogenic colonic perforation. Gastrointest Endosc 1997; 46: 464-466

2 Mana F, De Vogelaere K, Urban D. Iatrogenic perforation of the colon during diagnostic colonoscopy: endoscopic treatment with clips. Gastrointest Endosc 2001; 54: $258-$ 259

3 Dhalla SS. Endoscopic repair of a colonic perforation following polypectomy using an endoclip. Can J Gastroenterol 2004; 18: 105-106

4 Barbagallo F, Castello G, Latteri S et al. Successful endoscopic repair of an unusual colonic perforation following polypectomy using an endoclip device. World J Gastroenterol 2007; 13: 2889-2891

\section{Bibliography}

DOI $10.1055 / \mathrm{s}-0030-1255718$

Endoscopy 2010; 42: E213 -E214

(c) Georg Thieme Verlag KG Stuttgart · New York . ISSN 0013-726X

\section{Corresponding author}

\section{Senadhi}

Johns Hopkins University/

Sinai Hospital Program in Internal Medicine 2606B Gage Court

Baltimore, MD 21209

USA

Fax: +1-678-623-5999

vsenadhi@hotmail.com 